\title{
LÄHIKUVASSA MEDIAKASVATUS
}

Lähikuvan edellinen mediakasvatuksen teemanumero julkaistiin noin neljännesvuosisata sitten. Vaikka vuoden 1992 mediamaisema poikkeaakin nykyisestä, tuolloin pinnalla olivat likipitäen samat kysymykset mediaan liittyvistä kasvatuksellisista pyrkimyksistä kuin tänäänkin. Nämä kysymykset voi kiteyttää yhden ydinajatuksen ympärille: Miten taata kasvatuksen perimmäinen tavoite, hyvä elämä yhteiskunnan aktiivisena toimijana, varttuville sukupolville elämän eri vaiheissa?

Audiovisuaalisen kulttuurin tieteelliselle julkaisulle mediakasvatus on yhtä luonteva teema nyt kuin se oli edellisen teemanumeron ilmestymisen aikaankin. Audiovisuaalisen kulttuurin ilmiöt ovat edelleen mediakasvatuksen ytimessä. Tällä hetkellä keskustelua herättävien aiheiden - vihapuheesta algoritmien ohjaamaan elämään ja pelien koukuttavuuteen - takana oleviin mekanismeihin päästään käsiksi audiovisuaaliseen kulttuuriin kiinnittyvän mediakasvatuksen kautta.

\section{Mediakasvatuksen suuntauksia}

Mediakasvatuksella on pyritty ajasta riippuen kasvattamaan joko kuuliaisia kansalaisia tai aktiivisia toimijoita (ks. esim. Kupiainen et al. 2007). Kaikuja näistä aikaansa sidotuista näkökulmaeroista kuitenkin kuuluu edelleen esimerkiksi taidekasvatuksellisia, esteettisiä päämääriä vaalivia vaatimuksia tai voimauttavaa toimijuutta korostavissa äänenpainoissa.

Suojelullisilla näkökulmilla on mediakasvatuksessa pitkä historia, eivätkä käsitykset lapsuudesta varjeltavana viattomuuden tilana ole vieraita nykyiselläkään mediakasvatuksen kentällä sen huomattavasta moniäänistymisestä huolimatta (ks. esim. Postman 1994; Buckingham \& Chronaki 2014; Carlson 2012; Egan \& Hawkes 2010; Jones 2011). Vaikka mediakasvatukseen liittyvä huolipuhe korostuu edelleen alaikäisten median käyttäjien kohdalla, viime vuosina vaatimukset aikuisväestön mediakasvatuksesta ovat saaneet hyvinkin huolestuneita äänensävyjä niin kotimaassa kuin globaalistikin (Rasi et al. 2016; Pääärvi \& Palsa 2015; Livingstone ym. 2012). Disinformaatioon, valemediaan ja sosiaalisessa mediassa lietsottavaan vihapuheeseen liittyvät huolet ja pelot 
ovat saaneet monet peräänkuuluttamaan erityisesti aikuisten mediataitojen vahvistamista. Toisaalta myytti diginatiiveista (ks. esim. Kupiainen 2013) on saanut kysymään, ovatko lapset ja nuoret sittenkään aikuisia mediataitoisempia. Negatiivisiksikin koettuihin media-ilmiöihin on tuonut uusia näkökulmia ja tarttumapintoja edelleen ajankohtainen mediasuhteiden - sekä yksilöllisten että yhteisöllisten - pohtiminen. Mediasuhteissa on yhtäältä kyse jatkuvasta yksilöllisestä identiteettityöstä, toisaalta yhteisöllisestä vuorovaikutuksesta. (Ks. Kotilainen 2009.)

Mediakasvatus-kattokäsitteen takana on varsinainen termiviidakko, nyt jo historian sivuille jääneestä audiovisuaalisesta kansansivistystyöstä ja joukkotiedotuskasvatuksesta lähtien (Kupiainen et al. 2007). Kuten mediamaisema ja sen muutos heijastavat oman aikansa ilmiöitä, saman tekee myös mediakasvatus erilaisine ilmenemismuotoineen, nimityksineen ja painotuksineen. Mediakasvatus on kuitenkin se suomalaisessa keskustelussa yleistynyt ja vakiintunut käsite, jonka kautta mekin pyrimme tätä laajaa kenttää avaamaan (medialukutaidon ja mediakasvatuksen moninaisista määritelmistä ks. esim. Palsa 2016).

Suomalaisen mediakasvatuksen kannalta keskeinen toimija, koulu opetussuunnitelmineen, vaikuttaa myös mediakasvatuskieleen ja sen kehittymiseen. Mediakasvatusta ei ole monien toiveista huolimatta saatu omaksi oppiaineekseen kouluihin, mutta medialukutaito on tavalla tai toisella huomioitu opetussuunnitelmatasolla peruskoulun alusta alkaen. 1980-luvun joukkotiedotusnäkökulmasta on kuljettu 1990-luvun viestintäkasvatuksen kautta 2000-luvun viestintä- ja mediataitoihin (Peruskoulun opetussuunnitelman perusteet 1985, 1994, 2004; Rokka 2011). Mediakasvatus sisältyy myös ensimmäiseen velvoittavaan valtakunnalliseen varhaiskasvatussuunnitelmaan (Varhaiskasvatussuunnitelman perusteet 2016). Opetussuunnitelmat ohjaavina asiakirjoina tuovat erityisellä tavalla esiin yhteiskunnallisia painotuksia. Pekka Rokka (2011) onkin väitöstutkimuksessaan todennut kysymyksen median vaikuttavuudesta olevan yksi opetussuunnitelmien keskeisiä politisoituneita teemoja. Mediakasvatuksen tavoitteiksi luettavat mediakriittisyys, aktiivinen osallisuus ja vaikuttaminen sekä ajankohtaisen media-aineiston käyttö opetuksessa kytkeytyvät näihin teemoihin (Rokka 2011, 312).

Viimeisin opetussuunnitelmauudistus (Peruskoulun opetussuunnitelman perusteet 2014) toi mukanaan monilukutaidon käsitteen, joka tuntuu vastaavaan monella tapaa pirstaloituvan maailman opetukselle esittämiin haasteisiin. Tällöin medialukutaito on osa erilaisten lukutaitojen kirjoa ja kielitietoista opetusta. Monilukutaito-termin taakse kätkeytyy tekstien moninaisuuden lisäksi myös kulttuurinen moninaisuus: monilukutaito tukee maailman ja sen kulttuurisen moninaisuuden hahmottamista. Monilukutaitoisuuteen sisältyy myös eettisten ja esteettisten kysymysten pohdinta. Erilaiset identiteetit, kielet ja tekstit kohtaavat monilukutaitoisessa maailmassa yhdenvertaisesti. (Ks. esim. Kupiainen et al. 2015.) Peruskoulun opetussuunnitelman perusteissa monilukutaitoiseen moninaisuuteen sisältyvät myös oppilaiden kotikulttuurit sekä lasten ja nuorten omat elämismaailmat. Sinällään pyrkimys perustaa opetus lasten ja nuorten kulttuurien ja maailmankuvien ymmärtämiselle on ollut läsnä opetussuunnitelmissa 1980-luvulta lähtien (Rokka 2011, 268), monilukutaidon käsite on vain tuonut tämän pyrkimyksen osaksi laajaa kielitietoisuutta.

Mediakasvatus ja sen termijohdannaiset - monilukutaitoa myöten - pyrkivät tarjoamaan vastauksia yhä monimutkaistuvan maailman haasteisiin. Maailman moninaisuuteen, moniäänisyyteen ja moninapaisuuteen heränneet 
kasvattajat ovat löytäneet uuden ankkurin monilukutaidosta. Monilukutaitokompetenssinkin takaa on kuitenkin viime kädessä löydettävissä kasvatuksen ja ihmisyyden ydinkysymykset.

Toimintakentän uusien haasteiden myötä myös tunnetaidot ja empatia osana mediakasvatusta ovat kasvattaneet merkitystään (ks. esim. Mustola 2009). Aivotutkimus tuo empatian merkitykseen kiinnostavaa lisävalotusta mm. parhaillaan meneillään olevassa Katri Saarikiven johtamassa Natural emotionality in digital interaction -tutkimushankkeessa. Ehkäpä empatia onkin peräti keskeisin mediataito, jota affektiiviset audiovisuaalisen median tuotteet parhaimmillaan vahvistavat tukien myös vuorovaikutusta ja toimijuutta. Myös hyvinvoinnin näkökulma on noussut entistä enemmän esiin mediataidoista puhuttaessa. Mediasisällöt voidaankin nähdä myös identiteetin rakennusaineksina, tunnetaitoja ja hyvinvointia kokonaisvaltaisesti tukevina voimavaroina. Itseilmaisu, itseymmärrys sekä eettinen toimiminen yhteisön jäsenenä näyttäytyvätkin tänä päivänä esimerkiksi esteettistä arvottamista merkityksellisempinä medikasvatuksen sisältöinä.

\section{Mitä jää marginaaliin?}

Koska mediakasvatuksen toimintakentän keskustelut näyttäytyivät meille teemanumeron toimittajille paikoin toisteisilta, olimme erityisen kiinnostuneita mediakasvatuksen tutkimuskentän löytämistä hiljaisuuksista, vähän tutkimuksellista huomiota saaneista teemoista ja ilmiöistä sekä sensitiivisiksi koetuista aiheista. Halusimme kartoittaa, mitkä ovat mediakasvatuksen tutkimuksen näkökulmasta toimintakentällä unohdettuja, sivuutettuja ja marginaaleja ilmiöitä. Etsimme tekstejä, jotka käsittelisivät erityisesti audiovisuaaliseen mediaan liittyviä kysymyksiä.

Tässä teemanumerossa mediakasvatukseen liittyvä tutkimus näyttäytyy ennen kaikkea monitieteisenä ja -alaisena kenttänä, jossa monenlaista mediaa tarkastellaan kasvatuksellisen viitekehyksen läpi. Mediakasvatusta itsessään, an sich, ei empiirisen aineiston valossa juurikaan numeron teksteissä käsitellä. Pikemminkin tämän numeron tekstit paneutuvat mediaan, mediakulttuuriin tai mediakulttuuristen ilmiöiden ja asioiden tarkasteluun kasvun, kasvatuksen tai kasvattavuuden näkökulmasta.

Käsissä olevan teemanumeron artikkeleissa, katsauksissa ja kirja-arvioissa painottuu sosiokulttuurinen näkemys mediasta ja kasvatuksesta. Sosiokulttuurinen painotus korostaa mediakasvatuksellisia toimenpiteitä nykyajan mediakulttuurissa toimivien medialukutaitojen edistämiseksi. Näiden kompetenssien nähdään esimerkiksi johtavan maailman parempaan ymmärtämiseen, tietojen, kokemusten, osaamisen ja tunteiden tarkempaan jäsentämiseen ja jakamiseen sekä ympäröivän yhteiskunnan toimintaan osallistumiseen ja vaikuttamiseen yhä aktiivisemmin.

Tanja Sihvosen ja Lotta Lehden tutkimusartikkeli tuo mediakasvatuksen joidenkin kommentaattorien nimeämään totuudenjälkeiseen (post-truth) aikaan, jolloin heikot mediataidot konkretisoituvat pahimmillaan valeuutisten leviämisenä, vähemmistöihin kohdistuvana vainona, vihapuheena, äärinationalistisina pyrkimyksinä ja jopa kansanmurhina. Sihvonen ja Lehti tarkastelevat sosiaalista mediaa itseilmaisullisen retoriikan ja astroturffaukseksi nimetyn ilmiön kautta. Astroturffaus on kirjoittajien mukaan organisaatiolähtöistä, tietoista ja harhauttamalla vaikuttamaan pyrkivää digitaalista viestintää, jota toteuttavat ruohonjuuritason mediakäyttäjät tai sellaisina esiintyvät henkilöt. 
Kirjoittajat tarkastelevat, miten itseilmailullinen retoriikka ja sen toteutumista tukevat sosiaalisen median käytännöt voidaan valjastaa astroturffauksen tarkoitusperiä varten. Sihvonen ja Lehti vertailevat astroturffausta sitä lähellä oleviin ilmiöihin, kuten työntekijälähettilyyteen, trollaukseen, vaikuttajaviestintään ja spämmiviesteihin argumentoiden, että astroturffaus on monitahoinen ilmiö, jonka tunnistaminen vaatii pitkälle kehittyneitä mediataitoja.

Älylelut ovat herättäneet huolestuneita äänenpainoja viimeisten parin vuoden aikana. Niiden nähdään olevan uhka lasten yksityisyydelle ja turvallisuudelle. Lisäksi nostalgiaan nojaavat kommentit ihannoivat niin sanotuilla perinteisillä leluilla leikkimistä älylelujen sijaan, sillä älylelujen nähdään uhkaavan mielikuvituksekasta leikkiä. Paradoksaalista kyllä, älylelut niittävät positiivisia kommentteja erityisesti niiden opettavaisuuteen liittyvien mielikuvien takia. (Autio 2017). Katriina Heljakan ja Pirita Ihamäen tutkimusartikkeli selvittää verkottuneiden älylelujen opetuksellista potentiaalia esiopetuksen välineinä tarkastelemalla esikouluikäisten lasten leikkiä näillä leluilla. Kirjoittajat lähestyvät tutkimusaineistoaan monilukutaidon, leikin ja oppimisen näkökulmista esittäen, että tietokoneisiin, mobiililaitteisiin ja verkkoyhteisöihin kytketyt älylelut muodostavat alustan, joka tarjoaa sekä uusia viihteellisiä että opetuksellisiakin kokemuksia nykyajan leikkijöille. Heljakka ja Ihamäki ovat kiinnostuneita siitä, miten älylelujen ja Lelujen Internetin opetukselliset tarjoumat vastaavat lasten leikissä havainnoituja ja toteutuvia leikin muotoja. Kirjoittajat näkevät verkottuneen esineleikin soveltuvan käytettäväksi osana suomalaista esiopetusta, mikäli verkottuneiden älylelujen käyttö on suunniteltua ja siinä huomioidaan leikkivälineiden monipuoliset tarjoumat sekä niiden edellyttämä monilukutaito.

Hyvinvointi on parin viimeisen vuoden aikana noussut yhdeksi digiajan mediakasvatusta luonnehtivaksi teemaksi. Erityisesti sosiaalista mediaa on joissakin yhteyksissä luonnehdittu huumeiden kaltaiseksi koukuttajaksi, joka uhkaa nykyihmisten hyvinvointia. Somettoman syyskuun kaltaiset kampanjat osaltaan laittavat ihmiset pohtimaan, miten eri somekanavat vaikuttavat heidän arkeensa. Laura Pönkäsen katsaus esittelee aivotutkimuksen näkökulmia mediakasvatuksesta käytyyn keskusteluun tarkastellessaan kasvoja ja katsetta digiajan vuorovaikutuksessa. Väitöstutkimukseensa pohjaten Pönkänen tarkastelee sosiaalisen vuorovaikutuksen medioitumisesta tehtyä tutkimusta ja tarkastelee aivotutkimuksen, psykologian ja mediakasvatuksen näkökulmista, millaisia vaikutuksia sekä digitaalisella että kehollisella kasvojen kohtaamisella on tunteisiin, tiedonkäsittelyyn ja sosiaaliseen vuorovaikutukseen (ks. myös Pönkänen 2017). Pönkänen argumentoi, miten aivotutkimuksen tuloksilla on merkitystä mediakasvatuksessa esimerkiksi medialukutaidon ja aktiivisen kansalaisuuden yhä tarkemmassa jäsentämisessä.

Opettajaopiskelijat ja mediakasvatus 2017 -selvityksen mukaan valtaosa opettajaopiskelijoista kokee pakollisten opintojensa mediakasvatussisällöt riittämättömiksi tulevaa ammattiaan silmälläpitäen. Selvityksestä käy ilmi, että opettajaopiskelijat kaipaavat enemmän opetusta mediakasvatuksen konkreettisista työtavoista opetus- ja kasvatustyössä. Anne Rajalan katsaus esittelee yhden konkreettisen mediakasvatuksen työtavan opetuksessa. Hän tarkastelee, kuinka dokumenttielokuvaa voi hyödyntää mediakasvatuksen käytännön työkaluna medialukutaidon ja kriittisen ajattelun edistämiseksi. Mediakasvatuksellinen sovellus pohjaa ajatukseen dokumenttielokuvan erityisestä suhteesta todellisuuden kanssa, joka tarjoaa työkaluja tarkastella omia ja muiden käsityksiä todellisuudesta ja totuudesta. 
Olemme iloisia voidessamme uudelleenjulkaista Turun yliopiston mediatutkimuksen professori emeritus Jukka Sihvosen artikkelin "Fugiendo vincimus! Isä, poika ja pyhä valta", joka ilmestyi vuoden 1992 Lähikuvan mediakasvatuksen teemanumerossa. Retrotekstiä siivittää Sihvosen reflektio 26 vuotta sitten kirjoitetusta artikkelista. Alkuperäistä artikkelia lukiessa tähdentyy se tosiseikka, että vaikka artikkelin spesifi elokuvakasvatuksellinen näkökulma ammentaa oman aikansa elokuva- ja televisiokasvatuksen aikalaiskeskusteluista ja täten tuo oman historiallisen perspektiivinsä tähän teemanumeroon, 1990-luvun alkupuoliskolla mediakasvatuksesta ja sen perusteista käytyä keskustelua sävyttivät debatit teknisistä uudistuksista (tuolloin videonauhuri), median parissa käytetystä ajasta ja median vaikutuksista samoin kuin nykyisinkin.

Uudelleenjulkaisun myötä kiitämme tänä syksynä eläköitynyttä Sihvosta maamerkeistä ja ajattelun avaimista, joita hän on tuonut mediakasvatuksen toiminta-ja tutkimuskentälle aina vuonna 1988 julkaistusta Liekehtivät nalleverhot: esseitä elokuva- ja televisiokasvatuksesta -tekstikokoelmastaan lähtien.

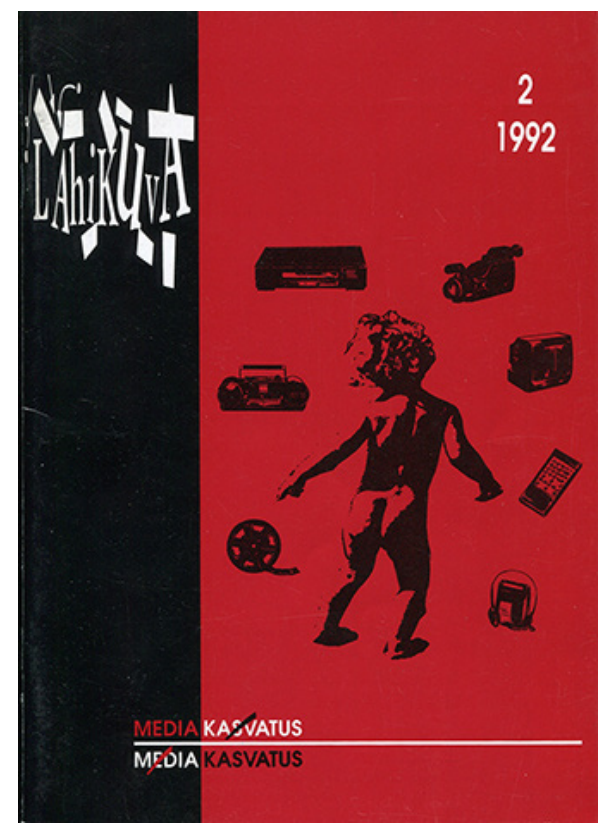

\section{Minne menet, mediakasvatus?}

Populaarikulttuurin ja -median tutkimus ovat olleet vahvoilla 1990-luvulta lähtien. Audiovisuaalisiin medioihin linkittyvään mediakasvatuksen kenttään on viime vuosina juurtunut yhä vahvemmin pelikasvatus ja sen mahdollisuudet. Lasten ja nuorten monipuolisen mediaympäristön ymmärtäminen vaatii kehittämään pedagogiikkaa, joka paitsi osallistaa kohderyhmänsä myös pyrkii ottamaan nuorille merkityksellisen mediakulttuurin kasvatustyön keskiöön.

Mediakasvatuksen teemanumero suomenkielisessä tieteellisessä aikakauslehdessä puolustaa paikkaansa, sillä suuri osa suomalaisesta mediakasvatukseen liittyvästä tutkimusraportoinnista julkaistaan kansainvälisillä foorumeilla. Mediakasvatus tarvitsisi kuitenkin edelleen suomenkielistä käsitteenmäärittelyä ja aktiivista monialaista keskustelua mediakasvatuksen tutkimuksen edistämiseksi ja käytännön mediakasvatustoimenpiteiden tueksi. Esimerkiksi mediakasvatuskonkarit Sirkku Kotilainen, Reijo Kupiainen, Sara Sintonen, Juha Suoranta ja Anu Mustonen ovat omalla tutkimuspanoksellaan vaikuttaneet merkittävästi suomenkielisen mediakasvatuksen kenttään ja termistöön. Toivottavasti mahdollisimman moni mediakasvatuksen tutkimuksesta kiinnostunut ottaisi osaa tähän keskusteluun myös jatkossa.

Mediakasvatuksen kehittämisen ytimessä on pitkälle medioituneen yhteiskunnan vaateet, jotka kumpuavat muun muassa alati teknologisoituvasta yhteiskunnasta ja kulttuurista, työn murroksesta, monikulttuuristumisesta ja kansainvälistymisestä sekä kiristyvästä taloudesta ja tuloksellisuuspaineista. Haastavat yhteiskunnalliset ilmiöt luovat painetta myös mediakasvatuksen tavoitteisiin. Monet kasvattajat kokevatkin yhä vaativammaksi pitkälle ke- 
hittyneiden "medialukutaidon kontekstualisoitujen osa-alueiden" (Palsa \& Ruokamo 2015) opettamisen. Mediakasvatukselle omat haasteensa asettavat myös eriarvoistumisen ja ilmastokriisin kaltaiset merkittävät mullistukset.

Pitäisikö mediakasvatuksen siis tähdätä kriittiseen kansalaisuuteen kasvattamiseen, selviytymiseen valeuutisviidakossa vai aktiiviseen toimijuuteen ja syrjäytymistä ehkäisevään osallisuuteen? Vaikka mediamaisema muuttuu, perusasiat pysyvät. Mediakasvatuksessa on kyse lopulta läsnäolosta, tunnetaidoista ja mielikuvituksella ruokitusta empatiasta. Mediakasvatuksen tavoitteena on ehkä sittenkin tunnetaitoinen, empaattinen yksilö, jollaisista koostuvassa yhteisössä vihapuheellekaan ei ole sijaa.

Toivotamme antoisia hetkiä Lähikuvan mediakasvatus-teemanumeron parissa.

\section{Marjo Kovanen ja Sanna Spišák}

\section{Lähteet}

Autio, Riikka (2017) "Ne vakoilee ja mitä kaikkee muuta ne tekee": Diskurssianalyysi älyleluista käydystä keskustelusta. Pro gradu -tutkielma. Kasvatustieteiden tutkinto-ohjelma - Degree Programme in Educational Studies. Tampereen yliopisto.

Buckingham, David and Chronaki, Despina (2014) "Saving the children: Childhood, pornography and the Internet". Teoksessa Wagg, Stephen and Pilcher, Jane (eds.) Thatcher's Grandchildren. Basingstoke: Palgrave Macmillan, 301-317.

Carlson, Dennis L. (2012) The Education of Eros: A History of Education and the Problem of Adolescent Sexuality. New York: Routledge.

Egan, Danielle R. \& Hawkes Gail (2010) Theorizing the Sexual Child in Modernity. London: Palgrave Macmillan.

Jones, T. M. (2011) "Saving Rhetorical Children: Sexuality Education Discourses from Conservative to Post-modern". Sex Education: Sexuality, Society, and Learning 11 (4), 369-387.

Kotilainen, Sirkku (2009) "Johdanto: Suhteet mediaan - avainkokemuksia nykykulttuurissa". Teoksessa Kotilainen, Sirkku (toim.) Suhteissa mediaan. Jyväskylän yliopisto: Nykykulttuurin tutkimuskeskuksen julkaisuja 99.

Kupiainen, Reijo (2013) "Diginatiivit ja käyttäjälähtöinen kulttuuri". Widerscreen 1/2013.

Kupiainen, Reijo \& Sintonen, Sara \& Suoranta, Juha (2007) "Suomalaisen mediakasvatuksen vuosikymmenet". Teoksessa Kynäslahti, Heikki; Kupiainen, Reijo \& Lehtonen, Miika (toim.) Näkökulmia mediakasvatukseen. Mediakasvatusseuran julkaisuja 1/2017.

Kupiainen, Reijo; Kulju, Pirjo \& Mäkinen, Marita (2015)"Mikä monilukutaito?". Teoksessa Tapani Kaartinen (toim.) Monilukutaito kaikki kaikessa. Tampere: Tampereen yliopiston normaalikoulu.

Livingstone, Sonia; Papaioannaou, Tao; del Mar Grandío Pérez, Maria \& Wijnen, Christine (2012) "Critical insights in European Media Literacy research and policy". Media Studies 3(6), 2-12.

Mustonen, Anu (2009) "Media tunnemyllynä". Teoksessa Kotilainen, Sirkku (toim.) Suhteissa mediaan. Jyväskylän yliopisto: Nykykulttuurin tutkimuskeskuksen julkaisuja 99.

Palsa, Lauri \& Ruokamo, Heli (2015) "Behind the concepts of multiliteracies and media literacy in the renewed Finnish core curriculum: A systematic literature review of peer-reviewed research". Seminar.net - International journal of media, technology and lifelong learning 11(2), 101-119.

Palsa, Lauri (2016) "Käsitteellisestä hajanaisuudesta medialukutaitojen moninaisuuteen". Teoksessa Pekkala, Leo; Salomaa Saara \& Spišák Sanna (toim.) Monimuotoinen mediakasvatus. Kansallisen audiovisuaalisen instituutin julkaisuja, 1/2016. Helsinki: Kansallinen audiovisuaalinen instituutti, 198-212.

Postman, Neil (1994 [1982]) The Disappearance of Childhood. London: W.H. Allen.

Pääjärvi, Saara \& Palsa, Lauri (2015) "Entäs aikuiset? - Katsaus medialukutaidon edistämiseen digitalisoituvassa Suomessa". Aikuiskasvatus 35 (3), 199-207. 
Pönkänen, Laura M. (2017) Flesh is Thicker than Bytes: Electrophysiological studies on the cognitive and affective processing of physical and digital faces. Acta Electronica Universitatis Tamperensis 1839. Tampereen yliopisto

Rasi, Päivi; Vuojärvi, Hanna \& Hyvönen, Pirkko (2016) "Aikuisten ja ikääntyneiden mediakasvatus". Teoksessa Pekkala, Leo; Salomaa, Saara \& Spišák, Sanna (toim.) Monimuotoinen mediakasvatus. Kansallisen audiovisuaalisen instituutin julkaisuja, 1/2016. Helsinki: Kansallinen audiovisuaalinen instituutti, 198-212.

Rokka, Pekka (2011) Peruskoulun ja perusopetuksen vuosien 1985, 1994 ja 2004 opetussuunnitelmien perusteet poliittisen opetussuunnitelman teksteinä. Tampere: Tampereen yliopisto. Kasvatustieteen yksikkö.

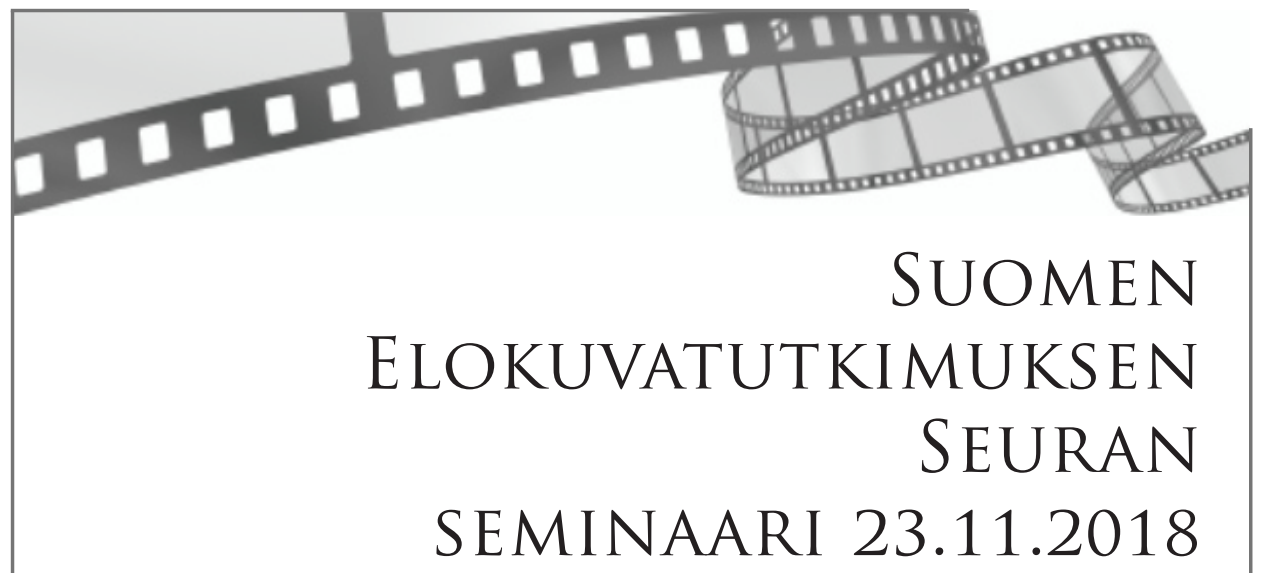

Suomen Elokuvatutkimuksen Seura järjestää perinteisen vuosiseminaarin elokuvan ja audiovisuaalisen median tutkijoille. Seminaari pidetään Helsingissä Tieteiden talolla perjantaina 23.11.2018.

Ohjelmassa on ajankohtaiseen tutkimukseen tutustumista, materiaaliesittelyjä, keskusteluja ja verkostoitumista. Mukaan ovat tervetulleita kaikki elokuvaa, televisiota, pelejä, av-mediaa tai niihin liittyviä aiheita tutkivat ja tutkimuksesta kiinnostuneet - niin graduntekijät, väitöskirjantekijät kuin väitelleetkin.

Osallistujia pyydetään valmistelemaan lyhyt esitys (n. 20 min) omasta tutkimusaiheestaan. Esitelmien maksimipituus ja aikataulu varmistuvat, kun osallistujamäärä on selvillä. Tilaisuuteen voi osallistua myös ilman esitystä.

Seminaarin jälkeen pidetään Suomen Elokuvatutkimuksen Seura ry:n syyskokous. Päivän päätteeksi on mahdollisuus jatkaa keskustelua ja viettää iltaa yhdessä.

Ilmoittaudu esitelmän pitäjäksi 22.10.2018 mennessä osoitteeseen elokuvatutkimuksen.seura@gmail.com.

Ilmoita sähköpostissa nimesi, yhteystietosi, organisaatiosi (esim. yliopisto/ oppiaine) ja esityksesi alustava otsikko.

Tervetuloa! 